\title{
Application of Permeable Pavement as Low Impact Development (LID) in Improving Water Quality in Semarang River
}

\author{
Anik Sarminingsih ${ }^{1 *}$, Mochtar Hadiwidodo ${ }^{1}$, Nurullah $^{1}$, and Khalisha Shafa Sausan ${ }^{1}$ \\ ${ }^{1}$ Department of Environmental Engineering, Faculty of Engineering, Diponegoro University, \\ Semarang, 50275, Indonesia
}

\begin{abstract}
The Semarang River is a flushing channel for the city of Semarang which is located in the Semarang River Drainage Sub-System. This river has the potential to become a water tourism area with the application of the Historical River Front City Walk concept. However, the water contained in the Semarang River still comes from the inlet of the residential drainage system which still uses a mixed system. The largest land uses are in the form of trade and service areas as well as high-density housing. This study aims to determine the percentage reduction in pollutant loads in the Semarang River Drainage Sub-System by implementing Low Impact Development in the form of a permeable pavement along the Semarang River Inspection road. The research method used SWMM software with the wash off function in the form of EMC. There are 11 observation points in the study area, starting from the Simongan Weir Bridge upstream of the river to the Berok 2 Bridge in the Kota Lama Semarang area. The simulation results show that permeable pavement can reduce pollution load with an average $\%$ decrease in TSS by $2,01 \%$, COD by $4,48 \%$, BOD $5 \%$ and Nitrate by $0,96 \%$.
\end{abstract}

\section{Introduction}

This decade, there has been a shift in the concept and paradigm of urban drainage system management, namely from conventional concepts to sustainable drainage concepts. Thus, there is a paradigm change that rainwater is a resource that must be managed that considers the usefulness or damaged power alone and needs to consider aspects of sustainability. Until now, there are several concepts of urban drainage system management based on rainwater management and runoff consisting of LID (Low Impact Development), SUDS (Sustainable Urban Drainage Systems), WSUD (Water Sensitive Urban Drainage Systems) and IUSM (Integrated Urban Stormwater Management) [1].

Until now, the application of LID is only applied by a few countries, so research on the effectiveness of the implementation of the new LID is relatively small [2]. Indonesia is a developing country where there has not been much application of LID in drainage systems. With complex problems, LID can be applied in developing countries by paying attention to

* Corresponding author: anikharieka@gmail.com 
various factors such as politics, socio-economic, cultural and technical mechanisms of drainage systems. One of the LID technologies that can be applied in Indonesia is Permeable Pavement.

In 2018, Semarang city was the fourth-best tourist city in Indonesia in Yokatta Wonderful Indonesia Tourism Award. This is motivated by the increasing number of tourists coming to Semarang, from 2.09 million tourists in 2011 to 5.02 million in 2017 [3]. Based on the presentation of Mr Teqi Wijaya as the Technical Design Section of the Semarang City Public Works Office on the Semarang City Government's Youtube page stated that the Semarang City Government has a planning arrangement on the Semarang River with the concept of Waterfront City that aims to allow the river in Semarang city to imply the concept of Historical River Front City Walk with the addition of space function on the river. Thus, the Semarang River not only serves to drain water but can also be used as a tourist attraction [4].

Semarang River is a city sewer located in the Semarang River Drainage Sub System. Semarang River gets supplies from Simongan Weir, located in The West Flood Canal (KBK). The most extensive land use in the Semarang River Drainage Sub System is trade and services areas. As the city's sewerage channel, Semarang River gets inputs derived from the inlet of the residential drainage system that still uses a hybrid system that combines drainage and wastewater disposal functions [5]. This can decrease the water quality in the Semarang River. Based on data from the Semarang City Environment Office from 2017 to 2019 stated that in the Semarang River, the parameters of water pollution that exceed the quality standards are TSS, TDS, Cd, DO (Dissolved Oxygen), $\mathrm{Cu}, \mathrm{Pb}, \mathrm{Zn}, \mathrm{Cr}$, Sulfide, Nitrit, BOD5 and COD.

Therefore, it is necessary to evaluate the water quality of the Semarang River. In this study, the study area consisted of two segments ranging from Simongan Weir Bridge as the upstream of the river to the Berok 2 Bridge in the Kota Lama Semarang area. The study area consists of two sub-districts, namely Central Semarang and South Semarang Subdistricts. We are modelling using SWMM 5.1 Software, which includes modelling hydrology, hydraulics, and the water quality of Semarang River.

\section{Purpose of the Study}

This study aims to determine the magnitude of the \%decrease in the average amount of wastewater pollutants in the Semarang River, including cod, BOD, TSS and Nitrate parameters with the application of Low Impact Development (LID) in the form of Permeable Pavement applied along the Semarang River Inspection Road starting from Tugu Muda Bridge to Berok 2 Bridge using SWMM 5.1 Software modelling.

\section{Method of Study}

The research method was conducted with field observation and literature study. Field observations were conducted by sampling the depth and quality of water in 11 points of Semarang River starting from Tugu Muda Bridge to Berok 2 Bridge. The observation data will be used as validation in SWMM Software 5.1. Furthermore, literature studies were conducted to find out lid type Permeable Pavement used in various developed countries suitable for application along the Semarang river inspection road. This modelling has three stages of analysis, including hydrology analysis, hydraulic analysis, and water quality analysis. 


\subsection{Description of Existing Conditions of Study Area}

The study site is located in the Semarang River Drainage Sub System, which is included in the Central Semarang Drainage System. Semarang River Drainage Sub System is the second-largest Drainage Sub System in Central Semarang Drainage System. As the object of research, the Semarang River is a city channel with a length of $8.25 \mathrm{~km}$ and an area of watersheds of $12,835 \mathrm{~km} 2$ [6]. Topography in the study area is a lowland with a slope of 0 $2 \%$ [7]. The soil types in the study area are primarily grey alluvial associations, and a small percentage are alluvial. Drainage systems in the study area use gravity systems and pumps.

\subsection{Tools and Material}

The tools and materials of this study are as follows:

- Semarang River water quality sampling data was taken on $03^{\text {rd }}$ and $05^{\text {th }}$ January 2021

- Rainfall data from the nearest station on $05^{\text {th }}$ January 2021

- Data on the depth of water level elevation of Semarang River

- DED drainage system of Semarang River Sub System

- Semarang River morphology data based on field observations

- Land use map

\subsection{Hydrological Analysis}

Hydrological analysis was carried out to obtain the value of minute rainfall, which will be used as input time series in SWMM 5.1 software. In the hydrological analysis, rainfall data comes from the Tanjung Emas Maritime Meteorological Station in Semarang City on 05th January 2021, which is $1 \mathrm{~mm} / 24$ hours. Furthermore, the rainfall data is converted into minute rainfall data using the Dr. equation. Mononobe as follows [8]:

$$
I=\frac{R_{24}}{24} x\left(\frac{24}{t c}\right)^{\frac{2}{3}}
$$

\subsection{Hydraulics Analysis}

The hydraulic analysis uses the dynamic wave method in the model, namely applying the one-dimensional Saint Venant flow equation. This method can simulate all variations in urban drainage flow conditions such as backflow, surcharged flow and flooding [9].

\subsection{Water Quality Analysis}

On the model using wash off function in the form of EMC (Event Mean Concentrations). This is because, in the study area, the source of pollutants in the non-point source. Thus, the use of EMC is considered more appropriate. The amount of EMC value is obtained based on previous research in various countries.

\subsection{Drainage System Modelling}

The first stage performed on the model is to determine the catchment area. The determination of the catchment area is based on the direction of flow contained in the DED (Detail Engineering Design) drainage system and the results of observations on the direction of the flow when conducting observations in the field and by paying attention to the contours that allow water to have flowed gravitationally. 
In modelling, the study area consists of 14 villages, where each village is divided into several sub-catchment so that there are 62 sub-catchments shown in (Fig. 1). The division of sub-catchment is motivated by differences in the flow direction.

Furthermore, in the drainage system modelling, there are 11 sampling points on the Semarang River that will be used as observation points on water quality modelling, as shown in (Fig. 2).

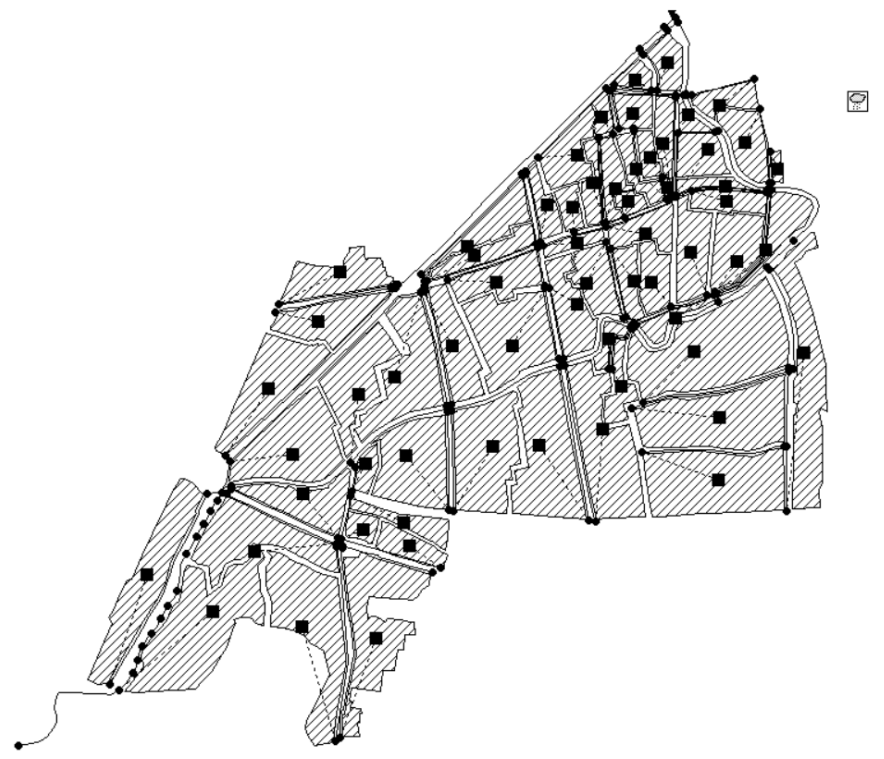

Fig. 1. Drainage System Modelling in Semarang River Sub System.



Fig. 2. Map of Semarang River Drainage Sub System Study Area. 


\subsection{Model Simulation}

Model simulations are performed using two scenarios. The first scenario is done by simulating the model in existing conditions. The second scenario is done by simulating the model using LID (Low Impact Development) in the form of Permeable Pavement.

In the first scenario, validation is performed on the model that aims to adjust the working model within the range of existing conditions. Validation is done by trial and error by performing numerical analysis. Numerical analysis is performed by evaluating RSME and NOF values of depth (water level elevation depth) and water quality [10]. Water quality validation also conducted trial and error on EMC value as a function on Wash off. The EMC value is obtained based on previous research from various countries because Indonesia does not have research related to the magnitude of EMC for domestic waste pollutants.

Furthermore, in the second scenario, SWMM 5.1 software modelling was carried out using the permeable pavement. (Table 1) below is the EMC value of the trial and error results in the model:

Table 1. EMC Values in the Study Location.

\begin{tabular}{|l|r|c|r|r|}
\hline \multicolumn{1}{|c|}{ Land-use } & COD (mg/l) & $\begin{array}{c}\text { BOD } \\
(\mathbf{m g} /)\end{array}$ & TSS (mg/l) & $\begin{array}{c}\text { Nitrate } \\
(\mathbf{m g} / \mathbf{l})\end{array}$ \\
\hline Residential & $231[11]$ & $60[13]$ & $548[14]$ & 4,5 \\
\hline Commercial & $201,38[12]$ & $42,3[12]$ & $338,46[12]$ & $0,09[15]$ \\
\hline
\end{tabular}

Source: Goore Bi et al (2015) [11], Thianhong (2016) [12], KNIER (2006)

[13], USEPA (1983) [14], Mark R (2003) [15]

\subsubsection{Existing Condition Model Simulation}

In the simulation of existing conditions, daily rainfall data on sampling day is January $5^{\text {th }}$, 2021, from the nearest rainfall station of $1 \mathrm{~mm} / 24$ hours. Then, the rainfall data is converted into minute rainfall, as shown in (Table 2).

Table 2. Minute Rainfall at Tanjung Emas Meteorological Station.

\begin{tabular}{|c|c|c|}
\hline $\begin{array}{c}\mathbf{T} \\
\text { (minute) }\end{array}$ & $\begin{array}{c}\mathbf{T} \\
\text { (hour) }\end{array}$ & $\begin{array}{c}\mathbf{I} \\
\text { (mm) }\end{array}$ \\
\hline 5 & 0,083 & 1,82 \\
\hline 15 & 0,25 & 0,87 \\
\hline 30 & 0,5 & 0,55 \\
\hline 45 & 0,75 & 0,42 \\
\hline 60 & 1 & 0,35 \\
\hline 120 & 2 & 0,22 \\
\hline 180 & 3 & 0,17 \\
\hline 360 & 6 & 0,10 \\
\hline 720 & 12 & 0,07 \\
\hline 1440 & 24 & 0,04 \\
\hline
\end{tabular}

Based on the results of simulation using SWMM 5.1 obtained the results of graphs of discharge relationship with water quality contained in figure 3 for observation point 1 , figure 4 for observation point 2, figure 5 for observation point 3 , figure 6 for observation point 4 , figure 7 for observation point 5 , figure 8 for observation point 6 , figure 9 for observation point 7 , figure 10 for observation point 8 , figure 11 for observation point 9 , figure 12 for observation point 10 and figure 13 for observation point 11 . 


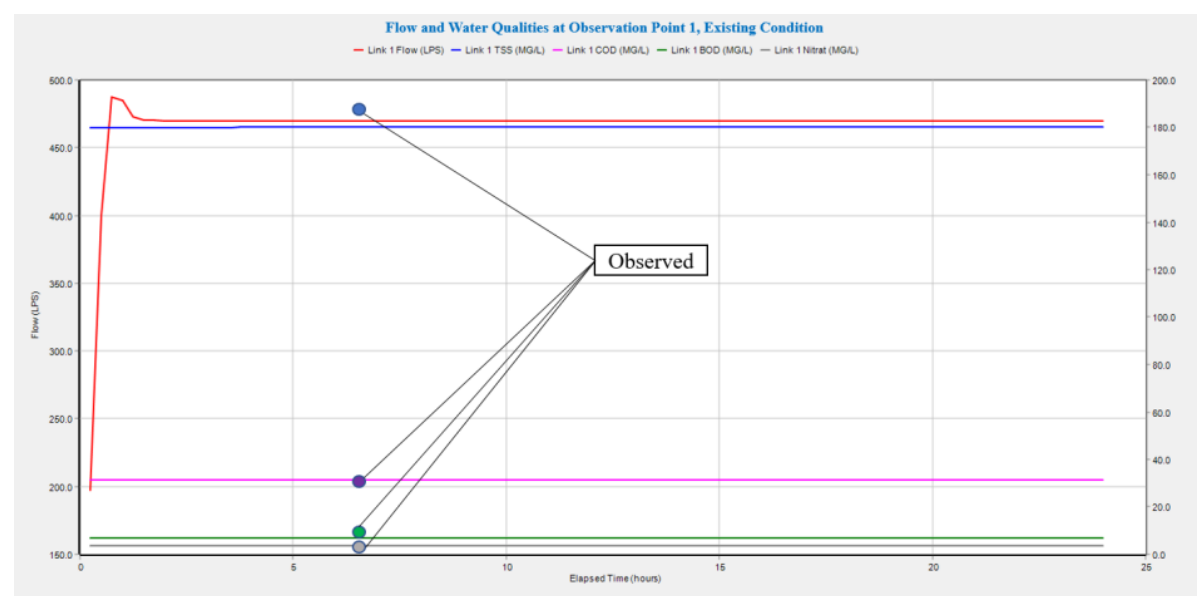

Fig. 3. Flow and Water Qualities in Existing Condition at Observation Point 1.

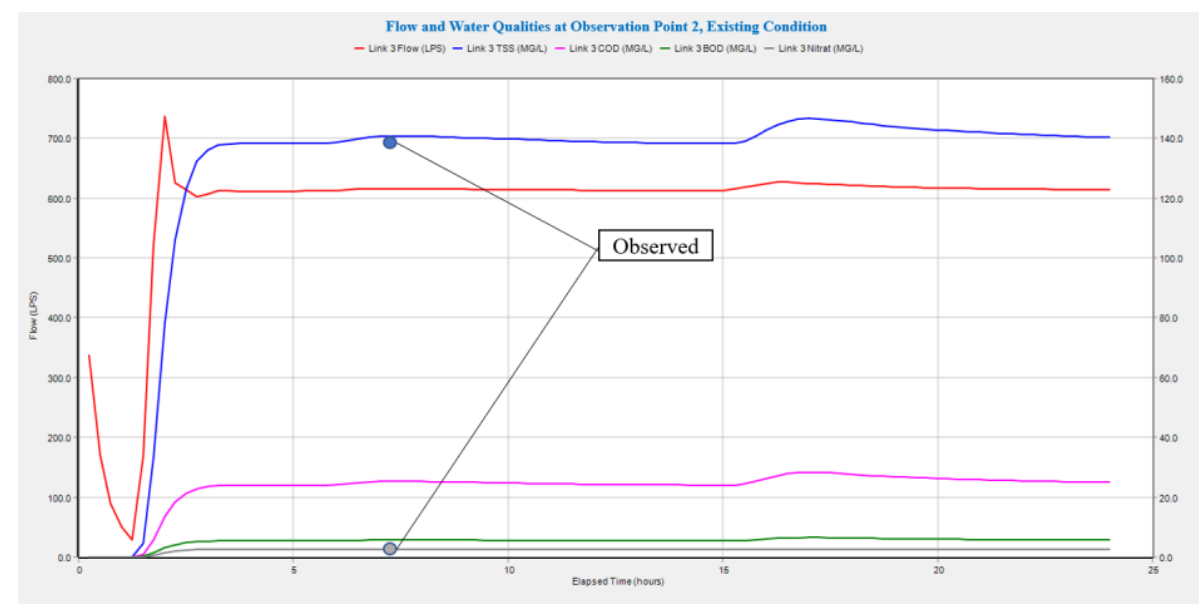

Fig. 4. Flow and Water Qualities in Existing Condition at Observation Point 2.

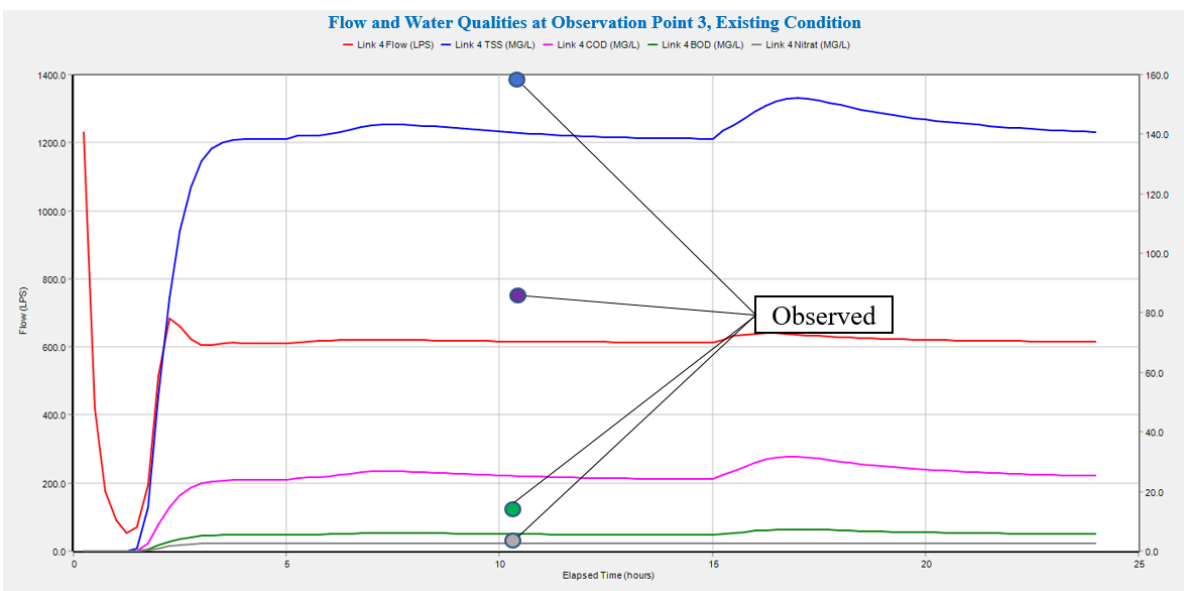


Fig. 5. Flow and Water Qualities in Existing Condition at Observation Point 3.

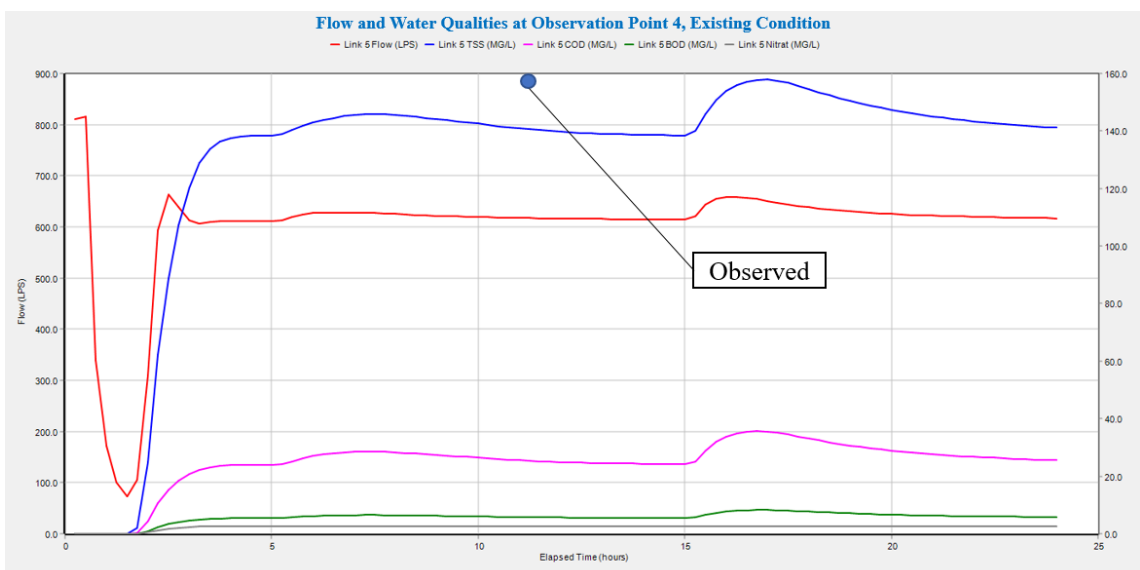

Fig. 6. Flow and Water Qualities in Existing Condition at Observation Point 4.

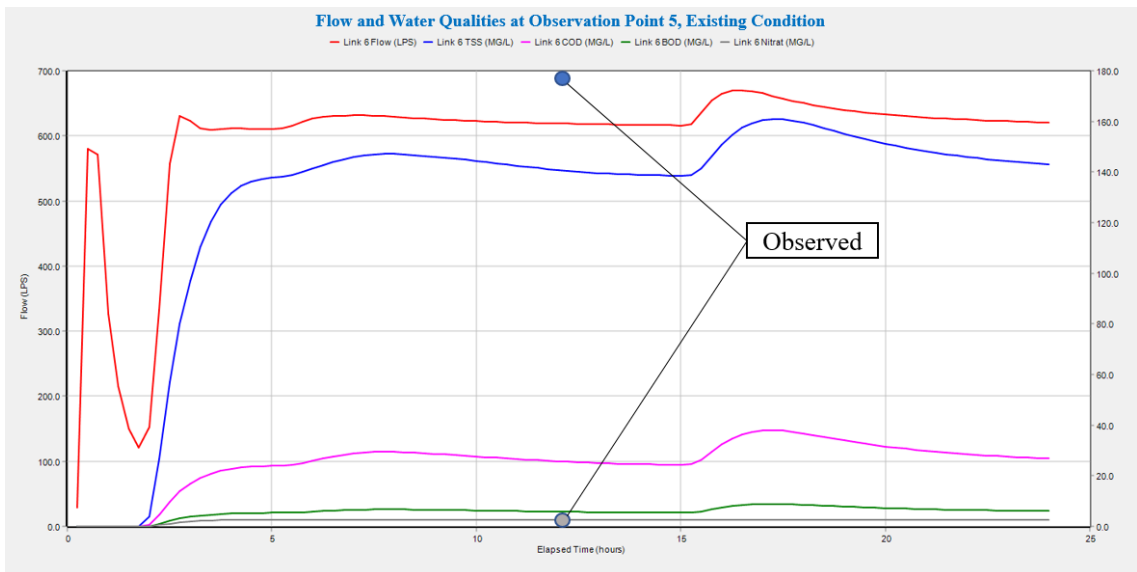

Fig. 7. Flow and Water Qualities in Existing Condition at Observation Point 5.




Fig. 8. Flow and Water Qualities in Existing Condition at Observation Point 6.

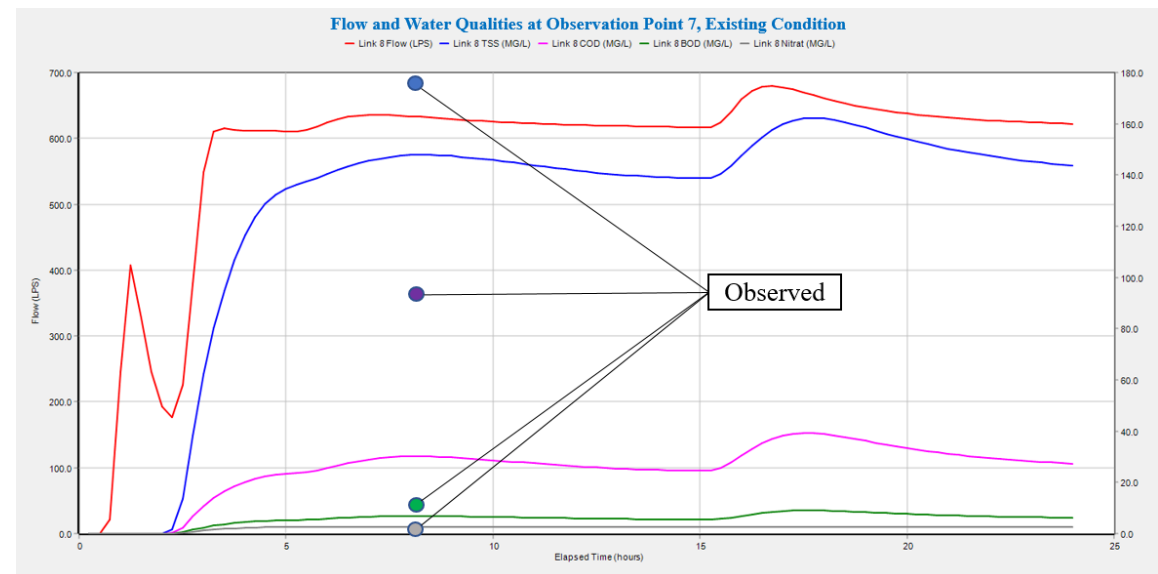

Fig. 9. Flow and Water Qualities in Existing Condition at Observation Point 7.

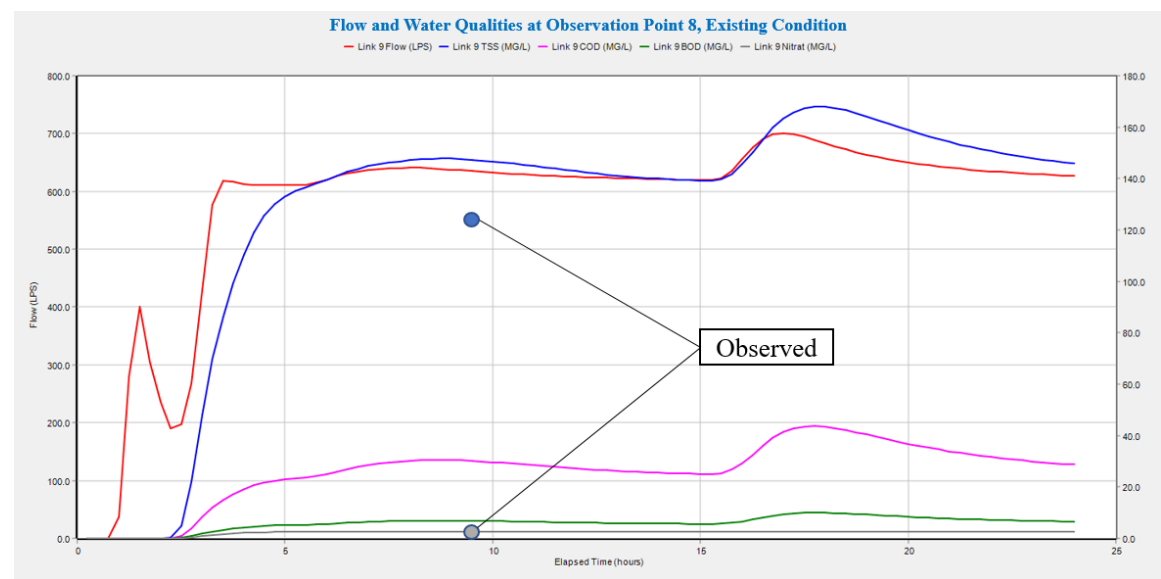

Fig. 10. Flow and Water Qualities in Existing Condition at Observation Point 8.




Fig. 11. Flow and Water Qualities in Existing Condition at Observation Point 9.



Fig. 12. Flow and Water Qualities in Existing Condition at Observation Point 10.

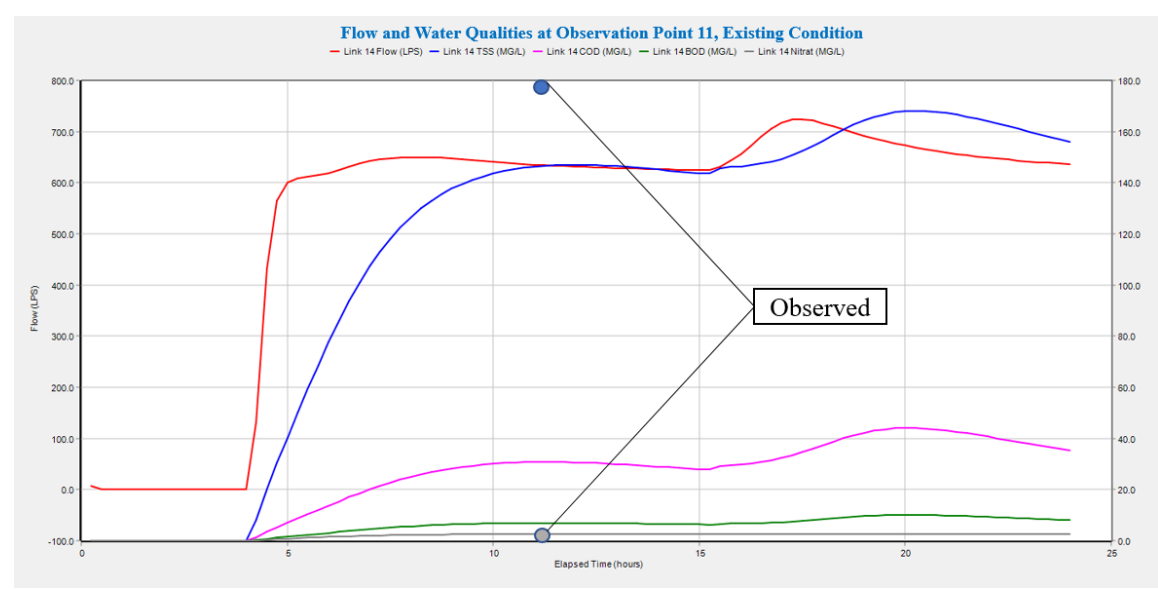

Fig. 13. Flow and Water Qualities in Existing Condition at Observation Point 11.

Based on the study results, the results were obtained that there are still some parameters that exceed the standard of river water quality class II for the provision of water infrastructure/recreational facilities, namely BOD, COD and TSS. The high value of COD in water is caused by the degradation of organic and inorganic materials derived from the domestic waste of the communities around the river and derived from industrial waste that is not well exposed. In addition, the high value of COD is also caused by the small value of flow speed in the river that causes the river challenging to degrade [16]. Then, the high value of TSS is thought to be caused by the presence of solid particles in the body of water that is the result of degradation of domestic waste derived from community settlements in the form of MCK (Bathing, Washing and Latrines) activities [17].

\subsubsection{Model Simulation Using LID}

To support the Semarang River as a water tourism area, the Semarang City government has planning arrangements for the Semarang River. One of them is building permeable pavement along Semarang river inspection road starting from Tugu Muda Bridge to Berok 
2 Bridge. This follows the planning in detail engineering design (DED) normalization of the Semarang River [18]. In addition to being one of the efforts to organize the river, permeable pavement can also improve runoff water quality.

In the simulation, permeable pavement used interlocking concrete pavement thickness of $80 \mathrm{~mm}$. (Fig. 14). Below is a cutout image of the permeable interlocking concrete pavement.

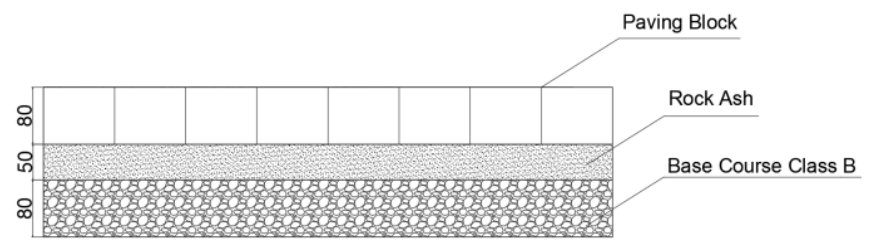

Fig. 14. Typical permeable pavement.

(Table 3) follows are characteristics of Permeable Pavement used in SWMM software modelling:

Table 3. Permeable Pavement Parameter Criteria.

\begin{tabular}{|c|c|c|}
\hline System Components & Parameter & Score \\
\hline \multirow{4}{*}{ Surface } & Berm Height & $80 \mathrm{~mm}$ [19] \\
\hline & Vegetation volume fraction & $0[19]$ \\
\hline & Surface Roughness & $0,1[19]$ \\
\hline & Surface Slope & $2[19]$ \\
\hline \multirow{7}{*}{ Pavement } & Thickness & $80^{1}$ \\
\hline & Void Ratio & $0,17[19]$ \\
\hline & Impervious Surface Fraction & $0[19]$ \\
\hline & Permeability & $400[20]$ \\
\hline & Clogging Factor & $0[19]$ \\
\hline & Regeneration interval & $0[19]$ \\
\hline & Regeneration fraction & $0[19]$ \\
\hline \multirow{7}{*}{ Soil } & Thickness & $50 \mathrm{~mm}$ \\
\hline & Porosity & $0,5[19]$ \\
\hline & Field Capacity & $0,2[19]$ \\
\hline & Wilting Point & $0,1[19]$ \\
\hline & Conductivity & $0,5 \mathrm{in} / \mathrm{hr}[19]$ \\
\hline & Conductivity slope & $10[19]$ \\
\hline & Suction Head & 3,5 in [19] \\
\hline \multirow{4}{*}{ Storage } & Thickness & $80 \mathrm{~mm}$ \\
\hline & Void Ratio & $0,75[19]$ \\
\hline & Seepage rate & $0,5 \mathrm{in} / \mathrm{hr}[19]$ \\
\hline & clogging factor & $0[19]$ \\
\hline
\end{tabular}

Source: Rossman (2016) [19], James Bruinsma (2017) [20] 
(Table 4) below is the \%removal allowance on permeable pavement used:

Table 4. \%Removal Allowance.

\begin{tabular}{|c|c|c|}
\hline No & Pollutant & \% Removal \\
\hline 1 & TSS & $86[21]$ \\
\hline 2 & COD & $14[22]$ \\
\hline 3 & BOD & $42,4[23]$ \\
\hline 4 & Nitrat & $35[19]$ \\
\hline
\end{tabular}
Source: Bodi Kimberly Liu et al (2020)
Ghisi Yu et al (2021) [22], Enedir
Ghisi [202], Rossman (2016) [19]

\section{Result and Assessment}

Based on (Fig. 3), it can be concluded that the concentration of pollutants TSS, COD, BOD and Nitrate is constant or linear along with increased discharge. This is because observation point 1 is the upstream part of the central drainage system that has not received input/input drainage settlements. Thus, the concentration of pollutants is of constant value. Furthermore, (Fig. 4), (Fig. 5), (Fig. 6), (Fig. 7), (Fig. 8), (Fig. 9), (Fig. 10), (Fig. 11), (Fig. 12), and (Fig. 13) have similar patterns of increase and decrease in concentration. That is, the concentration of pollutants will rise as the discharge increases until it reaches peak hours. Then, it declines again along with the decrease in discharge.



Fig. 15. Reduction of TSS Pollutant Load (Kg).




Fig. 16. Reduction of COD Pollutant Load (Kg).



Fig. 17. Reduction of BOD Pollutant Load (Kg).

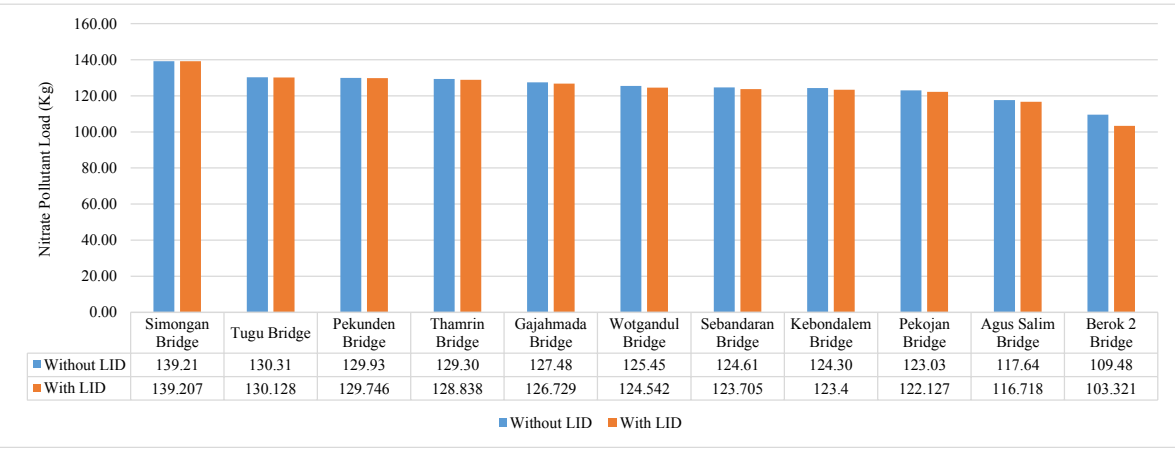

Fig. 18. Reduction of Nitrate Pollutant Load (Kg).

Based on (Fig. 15) above, it can be concluded that the decrease in a load of TSS pollutants occurred starting from Tugu Bridge to Berok 2 Bridge. The permeable pavement is only applied along the inspection road starting from Tugu Bridge to Berok 2 Bridge. The amount of \%decrease in TSS pollutant load ranges from $0.35-3.86 \%$, with a \%decrease in average pollutants by $2.01 \%$. Furthermore, Figure 16 shows that the magnitude \%decrease in pollutant load ranges from $0.83-8.69 \%$, with an average decrease in pollutants of $4.48 \%$. The amount of \%decrease in pollutants is directly proportional to the area of permeable pavement. The wider the application of permeable pavement, the \%decrease in pollutants will also be more significant.

(Fig. 17) shows that the magnitude \%decrease in BOD pollutant load ranges from 0.93 $-8.82 \%$, with a $\%$ decrease in average pollutants by $5 \%$. Furthermore, figure 18 shows that the magnitude \%decrease in nitrate pollutant load ranges from $0.14-5.63 \%$, with a $\%$ decrease in average pollutants by $0.96 \%$.

\section{Conclusion}

The modelling simulation was conducted using maximum daily rainfall data on January 05 , 2021, from Tanjung Emas Maritime Meteorological Station in Semarang city of $1 \mathrm{~mm} / 24$ hours. The results of sampling water quality at 11 observation points in the Semarang River still do not meet the quality standards following PP No. 22 of 2021. This is suspected because the water in Semarang River comes from the drainage of community settlements 
that still use mixed systems. One of the efforts to improve the water quality of the Semarang River is by applying permeable pavement along the Semarang River inspection road starting from Tugu Muda Bridge to Berok 2 Bridge. The permeable pavement application has an average allowance for TSS of $2.01 \%$, COD of $4.48 \%$, BOD of $5 \%$ and Nitrate of $0.96 \%$. However, the application of LID in the form of permeable pavement has not met the standard requirements of class II river water quality.

\section{Acknowledgement}

The author expressed his deepest gratitude to the Semarang City Public Works Office, Semarang City Environment Office, and other relevant agencies who have helped the author provide references in the form of secondary data in conducting this study.

\section{References}

1. Kementerian Pekerjaan Umum, Direktorat Jenderal Cipta Karya, Modul 8: Drainase Berwawasan Lingkungan (Ecodrain) (2013)

2. S. Zubelzu, L. R. Sinobas, I. A. Domenech, J. T. Castillo-Rodriquez, S. P. Mompaler, Design of Water Reuse Storage Facilities in Sustainable Urban Drainage Systems From a Volumetric Water Balance Perspective, 133-143 (2019)

3. N. L. Mardhiyani, Tourism 4.0: Strategi Komunikasi Pemasaran Pariwisata Kota Semarang, J. Kajian Media, 40-52 (2020)

4. Sarinastiti, R. S. Rukayah, T. W. Murtini, Konsep Waterfront pada Permukiman Etnis Kali Semarang, J. Teknik, 61-67 (2015)

5. Suripin, Sistem Drainase Pekotaan yang Berkelanjutan, Andi Offset Yogyakarta (2004)

6. Walikota Semarang, Peraturan Daerah Kota Semarang Nomor 14 Tahun 2011 tentang Rencana Tata Ruang Wilayah Kota Semarang Tahun 2011-2031 (2011)

7. Walikota Semarang, Peraturan Daerah Nomor 06 Tahun 2016 tentang Rencana Pembangunan Jangka Menengah Daerah Kota Semarang Tahun 2016-2021 (2016)

8. T. Bambang, Hidrologi Terapan, Beta Offset Yogyakarta (2014)

9. L. A. Rossman, Storm Water Management Model User's Manual Version 5.1, United States Environmental Protection Agency Cincinnati (2015)

10. M. F. Chow, Z. Yusop, M. E. Toriman, Modelling Runoff Quantity and Quality in Tropical Urban Catchments Using Storm Water Management Model, J. Environ. Sci. Technol, 9, 737-748 (2012)

11. E. G. Bi, F. Monette, P. Gachon, J. Gasperi, Y. Perrodin, Quantitative and Qualitative Assessment of the Impact of Climate Change on a Combined Sewer Overflow and its Receiving Water Body, Environmental Sciences and Pollutant Research, 11905-11921 (2015)

12. T. Li, F. Bai, P. Han, Y. Zhang, Non-Point Source Pollutant Load Variation in Rapid Urbanization Areas by Remote Sensing, Gis and the L-THIA Model: A Case in Bao'an District, Shenzhen, China, Environmental Management, 873-888 (2016)

13. KNIER, The Study of methods of assessing non-point pollutant loads (1) - centering on basic unit of roads and land (in Korean), Korea National Institute of Environmental Research, Incheon, South Korea (2006) 
14. U.S. Environmental Protection Agency, Results of the Nationwide Urban Runoff Program (NURP), Water Planning Division Washington DC, 1, NTIS PB 84-185552 (1983)

15. M. R. Lenz, S. Leggiero, G. Daviero, C. How, K. Naraghi, Rejuvenating Central Park, Water Environment \& Technology, 50-57 (2003)

16. P. S. Sara, W. Astono, D. I. Hendrawan, Kajian Kualitas Air di Sungai Ciliwung dengan Parameter BOD dan COD, Buku 1: Teknik, Kedokteran Hewan, Kesehatan, Lingkungan dan Lanskap, Cendikiawan Stats Jakarta, 591-597 (2018)

17. V. Pramaningsih, S. Suprayogi, S. Purnama, Kajian Persebaran Spasial Kualitas Air Sungai Karang Mumus, Samarinda, Kalimantan Timur, J. Pengelolaan Sumberdaya Alam dan Lingkungan, 7(3), 211-218 (2017)

18. Laporan Akhir, DED Peningkatan Kali Semarang (Tugu Muda-Johar) (2018)

19. L. A. Rossman, Storm Water Management Model Reference Manual Volume III Water Quality, United States Environmental Protection Agency Cincinnati (2016)

20. J. Bruinsma, K. Smith, D. Peshkin, L. Ballou, B. Eisenberg, C. Lurie, L. Haselbach, Guidance for Usage of Permeable Pavement at Airports, National Academies of Sciences, Engineering and Medicine Washington (2017)

21. B. K. Liu, N. P. Armitage, The Link between Permeable Interlocking Concrete Pavement (PICP) Design and Nutrient Removal, J. MDPI, 1-18 (2020)

22. Z. Yu, H. Gan, M. Xiao, B. Huang, D. Z. Zhu, Z. Zhang, W. Zhang, Performance of Permeable Pavement Systems on Stormwater Permeability and Pollutant Removal, Environmental Science and Pollution Research, 1-15 (2021)

23. E. Ghisi, T. Belotto, L. P. Thives, The Use of Permeable Interlocking Concrete Pavement to Filter Stormwater for Non-Potable Uses in Buildings, J. MDPI, 1-13 (2020) 